\title{
A Century AND A Half of CENTRAL BANKS, INTERNATIONAL RESERVES AND INTERNATIONAL CURRENCIES ${ }^{1}$
}

\author{
Barry Eichengreen and Marc Flandreau
}

June 2014

\section{Introduction}

In an insightful survey several years ago, Claudio Borio, Gabriele Galati and Alexandra Heath of the Bank for International Settlements reflected on trends in foreign reserve management. ${ }^{2}$ They noted an alignment of central banks' portfolio management strategies and standards with those of the private asset management industry. Central banks, they concluded, were increasingly concerned with profitability along with other, more traditional balance-sheet motives. They used many of the same standards and strategies as private fund managers in their efforts to pursue it. At the same time that reserve managers sought to balance returns with liquidity and safety, the authors went on, they also exhibited greater transparency and organizational transformations aimed at strengthening internal decision-making. Borio et al. noted further that, while these trends were visible for their population of central banks, there was also significant cross-sectional variation in central bank practice.

With the passage of time, the trends identified by these authors have only been reinforced, especially inasmuch as the consequences of the financial crisis of 2007 forced central banks to expand their balance sheets and take even larger positions. Another significant development since 2007 has been the multiplication of foreign exchange swap agreements, principally between the U.S. Federal Reserve System and other central banks, enabling those central banks to extend dollar repo lines to banks and firms. ${ }^{3}$

Our objective in this paper is to provide a historical perspective on central bank foreign exchange management, spanning the 150-plus years since the middle of the $19^{\text {th }}$ century. Compared to today, the issues then surrounding the holding of foreign assets by banks of issue, as central banks were known, were so simple as to appear almost rudimentary. Until the late $19^{\text {th }}$ century, foreign exchange reserves were a minor component of central bank balance sheets. National banks of issue, the majority of which were privately-owned, government-chartered companies, did in fact hold international reserve assets but principally in the form of bullion housed domestically or abroad. The so-called "reserve" was a guarantee of the circulation of banknotes and was made up of gold or silver bullion. This was a zero interest yielding asset, essentially dead weight for the profit and loss account.

Information on the reserve was deemed of great importance, although not all central banks were forthcoming about their holdings. Similarly, it was thought to be necessary and

\footnotetext{
${ }^{1}$ University of California, Berkeley and Graduate Institute of International and Development Studies, Geneva, respectively.

${ }^{2}$ Borio et al. (2008). The benchmark year for their study is 2006. The study resulted from an "ad hoc survey” of 28 central banks covering $80 \%$ of total reserve management.

${ }^{3}$ Paralleling this, the Federal Reserve has played an important role in shoring up dollar liquidity over and above its normal operations with U.S. financial institutions, including by lending directly to the U.S. subsidiaries of foreign financial institutions.
} 
desirable to impose regulatory requirements on what could be held as reserves, and where they could be held. The historical image, if we contrast it with modern practice as portrayed by Borio et al., is not of revenue-seeking asset managers engaging with international capital markets as part of their search for revenue, but rather of institutions connected to the external sector and to other central banks solely through fluctuations in their bullion reserve and the rules of convertibility.

This story is, in reality, too simple. Central banks already possessed some policy room for maneuver even when reserves were held wholly or principally in specie and strict gold standard rules tied the note circulation to the bullion reserve (Eichengreen and Flandreau 1997 is our distillation of this literature). There was an evolution in the reserve management practices from the late $19^{\text {th }}$ century away from holding the reserve entirely in bullion toward holding also foreign exchange reserves and using them to actively intervene in foreign exchange markets. The forms and patterns through which central banks were connected to the global economy were profoundly transformed over this longue durée.

Our paper tells the story of this transformation. While several previous studies have sketched the quantitative dimensions, much remains to be done in terms of tying the successive periods to one another and illuminating longer term economic and institutional developments. Ideally, one would wish to be able to construct consistent panel of central bank balance sheets spanning a long historical period. Unfortunately, much of the relevant data remains cloistered in the archives. Some is still regarded as too sensitive to release; other data has been selectively weeded or else destroyed in the course of war. Still, the recent literature has made headway in shedding additional light on specific aspects of the long run history of foreign exchange reserves. This permits us to develop here what may be the first systematic narrative account of the subject.

Our narrative develops three themes. The first theme traces the evolution of the principal reserve assets: the dominance of sterling before 1914, the rise of the dollar as a competing reserve currency in the 1920s, the retreat of sterling and then the dollar in the 1930s, and finally the persistence of sterling as a reserve asset followed by the dominance of the dollar after World War II. This now familiar narrative emphasizes the persistence of reserve currency status (put another way, the advantages of incumbency) but also the scope for challenges (often underestimated) by new reserve units. ${ }^{4}$ We provide more detail and nuance on these fluctuations what follows.

Our second theme emphasizes the rise of active reserve and portfolio management. The evolution we trace singles out the decades leading up to World War I as a first key period when a growing number of central banks accumulated foreign exchange reserves and began using them, via intervention in the foreign exchange market, in pursuit of a range of objectives. The central banks of Belgium, Austria-Hungary, Portugal, Spain and France emerge as key players in this period.

The interwar years were then a second key period of innovation. In this period additional central banks moved from following relatively mechanical gold standard rules and holding limited foreign exchange reserves, largely in a form linked to the currency of denomination of their governments' foreign borrowings, to more active management of their

\footnotetext{
${ }^{4}$ Again, this is a narrative to which we have contributed in our own work: see Eichengreen and Flandreau (2009) and Eichengreen (2011).
} 
reserve portfolios. ${ }^{5}$ This approach then suffered a setback in the 1930s, when financial volatility spiked and central banks incurred catastrophic balance-sheet losses. Not unexpectedly, similar practices were then suppressed after World War II, when capital flows and the international use of national currencies other than the dollar was strictly controlled.

But with the progress of financial and capital account liberalization in the second half of the $20^{\text {th }}$ century, the earlier trend toward active portfolio management on the part of central banks reasserted itself. Recent decades then constituted a third key period of transformation in which central banks moved further in the direction of active foreign reserve management, adopting practices that increasingly resembled those of private financial institutions.

Our third theme is the influence of politics. ${ }^{6}$ This link is evident before World War I in the dominance of sterling in the foreign exchange holdings of Britain's formal and informal empires (Mclean 1976). It is evident in the 1920s, when the Bank of England under Montagu Norman and Federal Reserve System under the leadership of Benjamin Strong competed in creating spheres of influence for sterling and the dollar (Chandler 1958). It is evident in the 1960s, when liquidation of dollars by the Bank of France reflected the aspirations of the French Republic to reassert its geopolitical influence in the face of American dominance, as well as familiar doubts about whether the dollar would hold its value. The question raised by this final theme is whether and how geopolitical considerations might now affect the reserve holding behavior of central banks going forward.

\section{The Early History of Central Bank Reserves}

The starting point for our narrative is the mid- $19^{\text {th }}$ century, when "reserves" (or, more precisely, the "reserve") meant coins and bars made of precious metals.

\section{a) Reserves Equal Bullion}

The practice of holding reserves grew naturally out of central banks' role as banks of issue. In more economically advanced countries, early modern monetary systems rested on legal tender laws that recognized coins made of gold and/or silver bullion as instruments for settling debts. To the extent that a bank of issue was allowed to issue notes without legal tender status, such notes were claims on specie. A critical element, therefore, was ensuring their quality by guaranteeing their convertibility. Convertibility meant that notes could be redeemed at the central bank's window and were thus "as good as gold (bullion)." For this to work, the central bank had to make good on that commitment. This is the standard explanation for how it was that early central banks held reserves in the form of gold and silver coins and bars.

Rules determining the requisite quantity of reserves differed across countries. In Britain and other countries following its example, a fixed amount of free issue was authorized, beyond which every banknote had to be fully backed by reserves (these were

\footnotetext{
${ }^{5}$ In the earlier period, before 1913, holding foreign reserves in the same currency as foreign borrowings were denominated was a way of hedging foreign exposures and smoothing debt service payments. In the 1920s, these earlier motives survived but were joined by the effort to maximize a combination of safety and return on the portfolio, in a manner reminiscent of modern mean-variance optimization. Or, rather, modern mean-variance of optimization is reminiscent of this earlier central bank practice.

${ }^{6}$ As we explain below, this is another traditional theme in the literature on foreign exchange reserve management practices, although we give it a somewhat different spin in what follows.
} 
countries with so-called fiduciary systems). Alongside there also existed systems where a maximum ratio of circulation to reserves was specified (so-called proportional systems). There could be further constraints. For example, the 1874 Spanish Law under which the Bank of Spain secured a monopoly of note issue stated that notes could not exceed four times bullion reserves and five times paid-in capital. Martín-Aceña, Martínez-Ruiz and NoguesMarco (2011) show that in practice the binding constraint was the latter and not the former.

As a result, the asset side of the balance sheet of a typical national bank showed the "reserve" (essentially bullion), a "portfolio" of short term bills that mostly included domestic instruments, and finally other investments, including domestic government debt, mortgage debts and so forth. The liability side showed capital, deposits, retained earnings, profits, and the value of outstanding banknotes. Contemporary analysis (e.g. Juglar 1862) suggested that this should be compared to the reserve to gauge the strength or willingness of the central bank to deliver on its commitments.

An implication of holding reserves entirely in bullion was that central banks, even when they transacted with one another or intervened on the foreign exchange market, transacted almost entirely in specie. Examples of this were instances of central bank swap lines (or central bank cooperation) in which one central bank lent reserves to another one (Eichengreen 1992, Flandreau 1997, 2004). These operations were conducted through the intermediary of a merchant bank, which would supply the foreign exchange counterpart. Central banks exchanged bullion against bills in domestic currency. Merchant banks stood between the principals and undertook the exchange of, say, francs for sterling.

\section{b) The Mystery of Bullion}

Convertibility and hence the reserve were so important because reliance on bullion was a technology for delegating authority to the central bank while still maintaining control of its actions. There was no consensus on alternative metrics, beyond the reserve, for measuring central bank performance. Specifically, there was no consensus on measuring prices: in the early $19^{\text {th }}$ century, for instance, it was felt that commodity prices were too volatile for "index numbers” of such prices to constitute a proper target for monetary policy. ${ }^{7}$ Ricardo's attacks on the Bank of England during the inconvertible paper currency period that coincided with the French Wars illustrate the enormous concern that early political economists and policy makers felt about the prospect of a central bank running monetary policy in the absence of proper rules.

Thus, the central bank's mandate was to target the value of the domestic currency in terms of an asset (gold or silver) whose price was readily observable and free of manipulation. The convertibility rule was a monetary policy target (preserving the external value of the currency) similar, in essence if not in methods and objectives, to modern inflation targeting. ${ }^{8}$ In practice the target was met by having the central bank standing ready to buy or sell bullion against notes at prescribed prices. That this target produced stable exchange rates when two or more central banks adopted it was incidental, just as the tendency for two countries to both

\footnotetext{
${ }^{7}$ As is evident from the Bullion Report and Ricardo's writings. It was not until Fisher (1922) that a measure of consensus regarding the measurement of inflation emerged. See Flandreau (2008) for a survey of historical disputes regarding the proper benchmark of currency depreciation.

${ }^{8}$ Bordo and Kydland (1995) prefer to think of this as a monetary policy rule rather than a target. Given the scope for exceptions (through, inter alia, temporary suspension) we prefer the present terminology.
} 
pursue explicit inflation-targeting regimes to enjoy relatively stable exchange rates vis-à-vis one another (Eichengreen and Taylor 2004) is incidental.

This interpretation is consistent with the famous British monetary policy debates of the first half of the $19^{\text {th }}$ century, with counterparts in other countries, which can be interpreted as disputes about the optimal contract for central bankers (see Fetter 1978). One view, associated with the Currency School, was that monetary and banking systems would be most resilient in the long run if money creation was tied to specie reserves. Members of this school essentially sought to transform the central bank into a currency board and supported the introduction of quantitative targets.

Because this was opposed by members of the Banking School, who favored a more flexible monetary policy attuned to the liquidity needs of the banking and financial system, a compromise, Peel's Act, was reached in 1844. This created in the Bank of England an Issue Department separate from a Banking Department, with the former in charge of issuing notes in amounts matching the bullion reserve, after allowing for an unbacked fiduciary issue of $£ 14$ million, while the latter was responsible for discounting bills, i.e. providing short-term secured loans to bankers, to the shadow banking system (leveraged bill brokers like Alexanders and Gurneys), and select commercial customers (Sayers 1932).

All this renders somewhat puzzling why central banks were still reluctant to hold and sometimes prevented from holding -- foreign exchange reserves. This is puzzling insofar as foreign exchange markets were far from primitive. The practice of holding foreign exchange bills and trading them in distant foreign exchange markets had been routine in banking circles since the Commercial Revolution of the $15^{\text {th }}$ and $16^{\text {th }}$ centuries. Every financial center of consequence had an active market for bills denominated in foreign currency. It was not unusual for private banks to accept payment in foreign exchange. Foreign exchange yielded positive interest when the nominal return on bullion was zero. Since the overwhelming majority of early central banks were privately owned, one would expect the profit motive to have prevailed.

One explanation for why foreign exchange could not be counted as part of the statutory reserve is that central banks faced stiff resistance from a banking system fearing competition. Central banks were tolerated as necessary sources of market liquidity, especially during crises, but they were not welcome competitors. The example of the Second Bank of the United States, which faced fierce opposition from banking circles and, not incidentally, engaged in the practice of selling foreign exchange to customers, illustrates the point (Bordo et al. 2007). It may be that central banks were prevented from including foreign exchange in their portfolios precisely because dominance of this market was a valued prerogative of other banks.

Another explanation is that holding foreign-currency-denominated claims required acquiring information about foreign correspondents, foreign signatures, etc., something that was not the comparative advantage of central banks. Rothschild and Morgan, in contrast, could rely on family links and personal connections abroad. That the problem was one of expertise explains why, as indicated above, central banks turned to leading private banks (that self-same Rothschild and Morgan) to assist them in market interventions as soon as they went beyond the comparatively simple task of managing a bullion reserve and ascertaining the quality of the financial instruments they discounted and took as collateral. 
A third answer is that law- and policy-makers hesitated to give central banks discretion over risk taking, given their responsibility for the convertibility of the currency. As we explain later, problems associated with investments in foreign exchange would indeed develop in the interwar years, when they resulted in major losses to central banks, in some sense vindicating earlier concerns. Contemporaries did not want central banks taking excessive risk that might jeopardize the value of the currency of which they were custodians. Profitability was therefore sacrificed in the interest of transparency, security and predictability.

\section{c) The Belgian Exception}

An early exception to these practices was the National Bank of Belgium (Conant 1910, Ugolini 2011, 2012). Founded in the aftermath of the 1847-1848 crisis with the goal of stabilizing the Belgian franc, the National Bank engaged virtually from the start in the practice of holding foreign exchange reserves. For accounting purposes, the Belgian central bank's foreign exchange reserves were kept separate from its specie reserve and reported along with domestic bills. When its charter was renewed in 1872, however, the statute was modified, allowing the Bank to hold foreign exchange as part of its official reserve.

The creation of the National Bank exhibited the interplay of competing interests and a general reluctance on the part of powerful discount banks to allow the new bank compete in the markets. Ugolini (2012) describes the "gentleman's agreement” between the government and the Bank, which had the Bank accepting, beyond its obligation to convertibility, a second, informal mandate of keeping market interest rates at low levels. Belgium had two very active foreign exchange markets, Brussels and Antwerp, that acted as hubs in the European money market. Interest rates there were sensitive to changes abroad because of pervasive arbitrage business (resembling the modern carry trade), in which investors shifted from low-return to high return ones (De Cecco 1990, Flandreau 1995). If one wanted to prevent the depreciation and increase in yields on Belgian francs that inexorably followed increases in yields abroad, the central bank had to sell foreign exchange and buy francs. But for this to happen, the central bank had to accumulate foreign exchange in the first place. Hence, the modification in its statute.

Ugolini describes the National Bank's reserve portfolio in 1851-53 as dominated by French francs, British pounds, Dutch guilders, and three German currencies (the Hamburg mark banco, Frankfurt guilder and Prussian thaler). While the identity of these currencies is not unexpected, the proportions in which they were held is striking. By far the most important foreign asset was the French franc (which made sense insofar as Belgium and France shared the same specie standard). ${ }^{9}$ French francs were the foundation of the National Bank of Belgium's foreign exchange portfolio and were held throughout. The proportions in which other currencies were held were adjusted in response to changes in yields. Interestingly, the pound sterling was only a minor reserve asset and wholly absent from the Bank's portfolio for much of the period.

The National Bank also set limits on the types of currencies that could be held. From the mid- $19^{\text {th }}$ century it committed not to hold inconvertible currencies in its investment portfolio (although such currencies could be posted as collateral with the Bank - see Ugolini 2011, p. 9). When in 1872 the Bank was permitted to include foreign exchange in the reserve,

\footnotetext{
${ }^{9}$ Technically, Belgium was silver based, while France was bimetallic. However, Belgium’s silver franc was patterned after the French silver franc.
} 
its charter still explicitly excluded inconvertible currencies, referring to "valeurs commerciales sur l'étranger, payables en numéraire” (“foreign trade bills, payable in specie”). This illustrates how contemporaries saw guaranteeing the value of the currency in terms of bullion and the holding of inconvertible currencies in the reserve as incompatible with one another.

\section{Europe’s Lombard Street Moment}

For many years, Belgium was praised by economists but without followers. When Japanese policy makers decided to pattern the statutes of the Bank of Japan after the "ideal” case of the Bank of Belgium, they conspicuously avoided authorizing the inclusion of foreign exchange within the official reserve, even when doing so was recommended in Count Matsukata's expert report in 1882 (Schiltz 2006). However, toward the end of the $19^{\text {th }}$ century, and despite the continued ban from the banknote "reserve," foreign exchange nonetheless managed to infiltrate the portfolios of central banks.

\section{a) The Rise of Official Reserves before World War I}

As described by Lindert (1969) the years leading up to World War I saw a remarkable expansion of the practice of holding foreign exchange reserves. By 1910, the ratio of foreign exchange to gold reserves held by official institutions reached roughly $1: 4{ }^{10}$ In the overwhelming majority of cases, this occurred not by including foreign exchange in statutory reserves but through the accumulation of a separate portfolio.

The dispersion of individual foreign exchange holdings was enormous. On the one hand, some countries such as Britain still did not hold foreign exchange. At the other extreme was the Bank of Japan, where, now emulating rather than shunning the Belgian example, the ratio of foreign exchange to gold reserves reached 1:1, a remarkable evolution given that those reserves were not part of the statutory gold reserve and had thus been accumulated despite the absence of any legal requirement or institutional incentive. ${ }^{11}$

The accumulation of foreign exchange reserves centered on the handful of currencies that Lindert described as "key currencies," in descending order of importance: the British pound, the French franc and the German mark, all of which had exhibited stability in terms of gold (suggesting that the explicit rules that the Bank of Belgium had formulated were implicitly adhered to in other places). These currencies had special status in the international monetary system in that they were traded in the largest number of foreign exchange markets and were most liquid as a result. Analysis of interest rate differentials supports the view (often expressed by contemporaries) that the use of these currencies by institutional investors (public and private) in turn fed back on the liquidity of these currencies in a virtuous circle fashion (Flandreau and Jobst 2005, 2009).

\section{b) The Politics of Key Currencies}

\footnotetext{
${ }^{10}$ The figure includes governments

${ }^{11}$ Its balance sheet in late 1909 showed 221 million yen in gold and ingots but a slightly larger amount (242 million yen) held in foreign exchange, including bills and remunerated foreign deposits with correspondents (Lévy, 1911 p. 257); The circulation of notes was 352 million, so that the cover ratio strictly defined (monetary liabilities relative to bullion reserves) only stood at $62 \%$.
} 
The rise of key currencies as investment vehicles for central banks was supported by a combination of market forces, institutions and, not least, politics. Global trade expanded rapidly in the 1840s and 1850s. Traders made arrangements with correspondent bankers in leading centers where drawing facilities (which provided the ability to source trade credit and deposit receipts) were cheap and reliable. Correspondents securitized the resulting credits as "acceptances" and assisted with their placement and distribution. Money market funds were established and expanded to invest in these instruments, giving rise to a large shadow banking system. London and Paris were the leading centers for this process.

The 1866 crisis triggered by the failure of an important constituent of this shadow banking sector, Overend \& Gurney, resulted in a liquidity crisis in London. The crisis was resolved by the Bank of England, which temporarily suspended the convertibility of notes into gold and distributed cash to all who could post adequate collateral. Because the subsequent resumption of convertibility was widely anticipated, this action addressed immediate liquidity needs without endangering the exchange rate. The episode heralded the subsequent rise of international currencies subject to complex commitments, rules and options (Bordo and Kydland 1995, Flandreau and Ugolini 2013).

An important document highlighting the political dimension of these arrangements is the circular that the British Foreign Secretary addressed to all diplomatic representatives a few days after the eruption of the crisis, asking British agents abroad to convey the message that British authorities were prepared to do whatever it took (to paraphrase Mario Draghi) to support the money market. The circular provided an account of the episode as a liquidity crisis and emphasized that the market was fundamentally sound. When making reference to the generous lending policy of the Bank of England, it emphasized that the policy of the Bank was fully endorsed by Her Majesty's Government, which was determined to act and would secure parliamentary support if need be. ${ }^{12}$ This was a powerful message. It signaled in unambiguous terms that when the soundness and continuity of operation of the London market was at stake, the British authorities would not be constrained by red tape or other formalities.

A second factor supporting the rise of key currencies in this period was the growth of overseas lending. The final decades of the $19^{\text {th }}$ century saw an enormous increase in bond flotations on behalf of foreign and colonial borrowers in London, Paris and Berlin. Bonds floated in these centers on behalf of overseas borrowers were predominantly denominated in the currency of the lending country (Flandreau and Sussman 2005). This was a matter of convenience and tradition; it appealed to the domestic clientele of retail investors. When governments and private parties borrowed in, say, London, they incurred a sterling denominated liability. It thus made sense for their agent, the central bank, to hold sterlingdenominated assets as insurance. These could then be lent to the principals in the event of liquidity problems affecting their ability to meet their debt service obligations. In the same way that the growth of foreign trade and foreign exchange reserve holdings went together, the growth of foreign lending and the holding of exchange reserves complemented one another. ${ }^{13}$

\footnotetext{
${ }^{12}$ The Circular went on to state: "The Bank of England is prepared to extend relief to the utmost of its means, to all cases which are justly deserving of its support; while Her Majesty’s Government, in full reliance on the eventual sanction of Parliament, if it should be necessary to go beyond the law as it now stands, have signified to the Bank of England their permission to hold itself free from the observance of the ordinary limitations on its issues, if the exigencies of the time require such an extraordinary measure" Patterson (1870).

${ }^{13}$ We give examples of this self-insurance behavior below.
} 
Again, political factors lay behind the connection. While H.M. Government generally took a hands-off policy toward overseas lending, the French and German governments actively promoted such lending as a means of strengthening diplomatic alliances. ${ }^{14}$ They were happy to see domestic capital flow to potential allies and for those allies, through their central banks, to in turn hold balances in foreign exchange in the respective financial centers.

Though sterling had few serious rivals, one significant rival was the French franc, as we saw in the case of Belgium; the same was true of a number of members of the Latin Union (Switzerland for example). In the years following the Overend \& Gurney crisis, Paris as a financial center was growing on the back of France's expanding trade and foreign capital exports, low interest rates and abundant gold reserves (Cameron 1960), the last of which enabled the Bank of France to set a narrower gold bid-ask spread than the Bank of England (Flandreau 2004). It almost seemed as if France and the franc were poised to threaten the dominance of sterling.

Thus, the international monetary and financial system might have developed in a different direction in the absence of the Franco-Prussian War of 1870-1 and the Paris Siege, which disrupted payments and led to a moratorium on the payment of French bills, dealing a blow to Paris' international financial aspirations. Another blow was the extended period of inconvertibility resulting from Germany's adoption of the gold standard and disposal of the silver standard (formally until 1876 but informally until 1873). In response, the Bank of France set out to stabilize the gold price of the franc. As Bagehot remarked,

"The note of the Bank of France has not indeed been depreciated enough to disorder ordinary transactions. But any depreciation, however small — even the liability to depreciation without its reality — is enough to disorder exchange transactions. They are calculated to such an extremity of fineness that the change of a decimal may be fatal, and may turn a profit into a loss. Accordingly London has become the sole great settling-house of exchange transactions in Europe, instead of being formerly one of two. And this pre-eminence London will probably maintain, for it is a natural pre-eminence. The number of mercantile bills drawn upon London incalculably surpasses those drawn on any other European city; London is the place which receives more than any other place, and pays more than any other place, and therefore it is the natural clearinghouse." 15

Thus, those who held sterling bills payable in London knew that, in times of crisis, such bills would always be cashable at (that their liquidity would be guaranteed by) the Bank of England. They understood from their behavior during the Overend \& Gurney crisis that officials would strive to ensure that banknotes remained convertible into gold. Sterling was liquid and secure. The readiness with which a sterling bill could be cashed made it as good as gold. Indeed, the interest it threw off made it superior. In a famous passage in Lombard Street (1873), Bagehot described this mechanism as forming the heart of the ascent of sterling as the world currency.

"The whole liability for such international payments in cash is thrown on the Bank of England. No doubt foreigners cannot take from us our own money; they must send here value in some shape or other for all they take away. But they need not send cash; they

\footnotetext{
${ }^{14}$ We qualify this view of the British authorities so-called "hands-off policy" in some respects in Section IV below.

${ }^{15}$ Bagehot (1873) p. 33-35.
} 
may send good bills and discount them in Lombard Street and take away any part of the produce, or all the produce, in bullion. It is only putting the same point in other words to say that all exchange operations are centering more and more in London.”

It is important to remember that Bagehot was not just a journalist but also a propagandist for the Liberal Party. He was involved in the political battle aimed at pushing the Bank of England to adopt a more aggressive role in dealing with crises. ${ }^{16}$ His claim that London was destined to dominate deliberately neglected the fact that any currency backed by a strong commitment to ensure its stability and liquidity could become eligible as "key currency.” Thus, Bagehot did not anticipate or at least did not wish to acknowledge that by opening the door to the possibility of substituting for gold another asset with a higher return, sterling might eventually have contend with competition from not just the French franc but also with the German mark, both of which were found in substantial amounts in the portfolios of official institutions on the eve of World War I. According to Lindert (1969), "while greater balances were held in London than in any other international financial center, a larger share was held in France and Germany than has been generally realized. The frequent portrayal of London as the major reserve center before WWI exaggerates somewhat."17

\section{Pre-WWI Motives for Accumulating Foreign Exchange Reserves}

Traditional explanations of the accumulation of foreign reserves have emphasized rising entanglements between politics and money management. Because the export of capital had significant implications for the management sterling, from the 1890s onward the Bank of England played an increasingly important role in colonial finance. Through the agency of the Crown Agents and London brokers and its influence over colonial governments, the Bank sought to restrain capital exports when money was tight and, conversely, provided inducements to borrow when it was abundant. Ability to follow such early and unconventional open market interventions intended to increase the effectiveness of official discount rate changes were evidently a product of Empire - of the leverage which London political and monetary authorities had over overseas borrowers (Sayers 1936, Sunderland 2004).

The result was a close relation with Empire, which de Cecco's pioneering study served to highlight (de Cecco 1974). In de Cecco's account, this connection resulted from the happy coincidence of the need to manage the convertibility of sterling on a "thin film of gold" with the structural position of the less developed countries under British political influence. Members of Britain's formal and informal empires borrowed from London in sterling and warehoused the receipts there. This was convenient from the standpoint of transactions; their sterling could be drawn on to service debt and pay for imports. It was also rational from the standpoint of hedging exposures. In other words, sterling balances in London served as an

\footnotetext{
16 This was a theme of Lombard Street, which actually led to a dispute with Hankey, a director of the Bank of England, who feared this would encourage moral hazard.

${ }^{17}$ Lindert (1969). See also Bloomfield (1963, p. 93). Lindert does not appear to have noted the fact that a substantial part of such holdings could be acquired in domestic money markets. That said, recent work by Flandreau and Gallice on the balance sheet of Banque de Paris et des Pays-Bas, France's largest investment bank and an important repository of foreign exchange deposits from the Russia Government and central bank, shows that this bank recycled its large liabilities (which had one point doubled the size of its balance sheet) through heavy investment in sterling bills. If this pattern was general (if it extended also to other investment banks), then official foreign deposits in francs and marks would have been themselves dependent on private sterling deposits, thus qualifying Lindert’s qualification (Flandreau and Gallice 2007).
} 
effective hedge against sterling-denominated debts. ${ }^{18}$ De Cecco gives a special place to India, emphasizing "the basic importance of India as the main stabilizing element." Through its London deposits, India (and other less advanced countries like Japan) permitted London to act as an intermediary in the short-term capital market. ${ }^{19}$

\section{a) Self-Insurance}

Another important motive for accumulating gold reserves is illustrated by the case of Russia, which was, along with Japan and India, one of the principal holders of foreign exchange in the pre-1914 period. Domestic opposition painted as an absurdity the maintenance by Russia of enormous short-term deposits in Paris at 2 per cent when the Bank of France's lending rate was 3 per cent and the Paris market was lending to Russia at 4 per cent. In response, the Russian authorities emphasized the perils of the political conditionality to which Russia would be subject if it had to borrow in an emergency. Self-insurance was therefore advisable. The argument thus anticipated on the modern interpretation that saw in the accumulation of Chinese reserves in the late 1990s a response to the Asian crisis (see Aizenman and Lee 2005).

In one of the rationalizations he provided for his government's extensive holding of foreign exchange reserves, the Czar's Finance Minister Sergei Witte clearly referred, in the language of his time, to the risks of "political conditionality" in situation of sudden stops:

"Generally, needs resulting from political events are unpredictable and when they occur, absolutely urgent. From [which] we can see that, if we did not have [foreign exchange] reserves, we would see ourselves, in such a circumstance, [having] either to sacrifice political interest or to borrow at any price. But then experience shows that states, like individuals, are often offered loans at attractive prices when they have not use for them, while by contrast, regardless of their solvency, they sometimes just can't find resources at an affordable price, when they need [them] urgently. In such situations, the lack of a pecuniary reserve might cause to the State a political prejudice.”20

Thus, when it comes to the insurance motive for holding foreign reserves (as an alternative to recourse to IMF or ESM assistance), there is little new under the sun.

\section{b) Interest-Rate Smoothing}

Studies for Belgium, the Austro-Hungarian Empire and France point in addition to the utility of foreign exchange reserves as an instrument for smoothing interest rate fluctuations. Historical evidence is indicative of widespread concern over sharp changes in interest rates (Conant 1910, Patron 1910, White 1930, Einzig 1931, Kauch 1950, Bordo and McDonald 2012). As Reis (2003) describes, sudden increases in interest rates were unpopular and triggered protests because they were perceived as "depress[ing] business, reduc[ing] trade and

\footnotetext{
${ }^{18}$ For more on this see Subsection b below.

${ }^{19}$ But the same argument might be made without reference to India's trade position, in the same fashion as, in the monetary approach to the balance of payments, it is the demand for money that drives the current account. Because the predominance of sterling was so important to British dominions, efforts to shore up of the cash position of London were supported by British political authorities, who encouraged the regions under their influence, to hold sterling balances. This provided for the defense of the London market and the rest followed. For a recent study of the organic link between Indian finance, the London money market and Empire see the recent book by Sunderland (2013).

${ }^{20}$ Quoted in Flandreau (2003), p. 46.
} 
production and provok[ing] urban unemployment and possibly unrest.” A further complaint about sharp changes in interest rates, especially in the upward direction, was that they had an adverse impact on the price of government bonds.

Fortunately, the gold standard left some room for intervening in the foreign exchange market to smooth such fluctuations, taking advantage of minor frictions and the limited exchange rate flexibility that existed within "gold points." Because shipping gold between markets entailed costs, exchange rates were only fixed up to the cost of shipping gold. Pushing the exchange rate down toward the gold export point created the expectation that it would revert toward the middle of the band; this expectation of subsequent appreciation in turn led investors to accept lower interest rates (Keynes 1930, Eichengreen and Flandreau 1997). Interest rate effects of this sort seem to have been the main reason for the Bank of Belgium's policy of holding foreign reserves and intervening in the foreign exchange market. The impression that its intervention was successful (as manifested in the fact that the secured interest rate on Belgian francs was often lower than rates in other leading markets) encouraged emulation.

One emulator was France. Contamin (2003) shows that interest-rate- smoothing motives help to explain why the Bank of France began acquiring sterling assets in the Paris foreign exchange market from private banks around the turn of the century. Because sterling paper was the most liquid global instrument and was held by all internationally-active banks, liquidity shocks in the London money market that forced the Bank of England to raise its discount rate could put pressure on the Bank of France. To prevent this, the Bank of France conducted countercyclical interventions on the Paris money market, buying sterling when the banks were selling and vice versa (Flandreau and Gallice 2007).

The behavior of the Austrian-Hungarian central bank was not dissimilar. Along with Japan, India and Russia, the Austro-Hungarian bank was one of the key holders of foreign exchange in this period. Einzig (1931), Flandreau and Komlos (2006) and Jobst (2009) describe its foreign exchange policy. The Austro-Hungarian bank was hailed by interwar economists like Keynes (who had been editor of the Economic Journal already before World War I, in whose pages these issues had been discussed) as an exemplar of successful monetary management for the way it relied on the foreign exchange market and in particular on forward market intervention in order to avoid having to continually adjust its interest rate to foreign levels (von Mises 1909; Keynes 1930).

Jobst shows that this was done using a range of sophisticated foreign exchange instruments that included the forward market and foreign exchange repo contracts. When British interest rates increased, the Austro-Hungarian central bank let the florin depreciate against the pound while intervening to push it up in the forward market, thus compensating investors in florins for the lower interest rates and preventing further fluctuations. Jobst also finds that during most of the period, the Austro-Hungarian bank was the main participant in the market for foreign exchange.

\section{c) Carry Trades}

A third motive for investing, or borrowing, in foreign exchange reserves may be described using the modern expression of carry trades a trading strategy that relies on perceived mispricing of interest rate differentials and exchange rates. In cases, foreign exchange reserves entered in both the asset and liability side of a central bank's balance sheet. 
Reis (2003) describes how the Bank of Portugal similarly borrowed in London to protect its reserves. In order to avoid a drain on its gold reserves, the Bank sold drafts on London at a discount (the equivalent of receiving deposits in sterling), in effect borrowing foreign reserves. Once the draft was sold, the Bank could invest the proceeds in Portugal, where interest rates were higher. The drawing of foreign exchange permitted it to avoid curtailing credit (as would have been the case if bullion had been sold, since cover ratio rules would have become binding forcing a reduction in the money supply). ${ }^{21}$

Martinez-Ruiz and Nogues-Marco (2014) suggest that the Bank of Spain did something similar during periods of domestic stringency, such as in 1882 and 1889-1891, when it borrowed foreign exchange from Banque de Paris et des Pays-Bas rather than using its reserves. Foreign bills paid 3.25 per cent at a time when Spanish interest rates were around 5 per cent. Thus, so long as the exchange rate remained stable, borrowing foreign exchange was a profitable transaction. Given the high interest rates which characterized so-called "peripheral” countries (Bordo and Flandreau 2003, Mitchener et al. 2012), similar "central bank-led carry trades" must have been considerable elsewhere as well. Although not recognized as such in the existing literature, this aspect of early central banking in the periphery ought to receive greater attention for the obvious connection it reveals with insider trading (since central banks could affect the exchange rate) and rent seeking (since central banks were perhaps in a better position than other market participants to perform such operations.

\section{The Rise and Fall of Genoa}

The 1920s and 1930s were pivotal decades for foreign exchange portfolio management by central banks. The period saw the rise and fall of the so-called gold-exchange standard. The idea of replacing the gold standard with a gold exchange standard, building on pre-war experience with key currencies, was fully articulated at the Genoa Conference in $1922 .{ }^{22}$ The Financial Commission of the conference was presided over by British Chancellor of the Exchequer Sir Robert Horne. It considered remedies for the perceived dangers of global deflation. The war and its aftermath had seen considerable monetary creation: return to the pre-war order implied “tapering” and, by implication, deflation and associated pressures, including unemployment. This was not an appetizing prospect for Western powers now haunted by the specter of the Bolshevik Revolution.

Along with this general concern with the future of Western capitalism were also specifically British concerns that returning to a gold standard along prewar lines would make it difficult for Britain to regain its position as a monetary center. Forced to adopt austerity measures, Britain would have to discourage capital exports and the provision of trade finance to foreign customers, creating a marketing opportunity for U.S. financial institutions.

This is how the Genoa Conference was led to reimagine the pre-war gold standard as having sowed the seeds of a superior gold exchange standard now to be implemented (Nurkse 1944, p. 29). The key innovation lay in the attempt to systematize the way foreign exchange reserves were handled and in codifying previously ad hoc practices. Resolution 9 of the report

\footnotetext{
21 The technique of drawing in London to invest in Portuguese securities might be described as an early case of the carry trade, this time however implemented by monetary authorities themselves.

${ }^{22}$ The League of Nation was prominently involved in promoting the gold exchange standard, and we owe to League's de facto chief economist Ragnar Nurkse the first post-mortem of the system (Nurkse 1944; see also Fior 2008 and Biltoft 2014).
} 
of the Financial Commission to the Genoa Conference declared that the aim of the convention would be to "centralize and coordinate the demand for gold, and so avoid those wide fluctuations in the purchasing power of gold which might otherwise result front he simultaneous and competitive efforts of a number of countries to secure metallic reserves." Resolution 11 stated that the "maintenance of the currency at its constant gold value must be assured by the provision of an adequate gold reserve of approved assets, not necessarily gold." 23

It may be an exaggeration to speak of a "Genoa Order" because, like so many other expert recommendations of the time, the agreements of the report of the Financial Commission fell to pieces subsequently. That said, many of the ideas had an enduring impact (Clavin 2013). The effect of Genoa was visible in the many financial stabilization programs adopted under the auspices of the League of Nations in the 1920s. In Austria, Danzig, Hungary, Bulgaria, Estonia and Greece, League of Nations "packages” included newly created or reorganized central banks with statutes that authorized them to hold foreign exchange as a component of their reserves (League of Nations 1932).

\section{a) The Mlynarski Dilemma}

The gold exchange standard envisaged at Genoa had inherent contradictions, including one that came to be known later as the so-called "Triffin paradox," after the Belgian economist Robert Triffin (1947), who leveled the same critique against the dollar-based Bretton Woods System. In the 1920s and 1930s the argument was identified with Feliks Mlynarski, the Polish-born economist and subsequently affiliate of the Financial Committee of the Lelague of Nations, who pointed to it in Mlynarski (1929). Under the gold exchange standard, the gold supply problem was simply replaced by the confidence problem of key currencies. This confidence problem would inevitably arise when foreign exchange reserves grew large relative to the gold stocks of the key-currency central banks, exposing the latter to the equivalent of a bank run problem. But it could arise even earlier as a result of instability on the London and New York markets and associated policy uncertainty, as events would soon reveal.

Austrian stipulations regarding which currencies the central bank could hold provide a case in point. Austrian statute stated that foreign currencies held as reserves would have to be not just convertible but also stable and liquid. The statutes adopted in the 1920s permitted investment in inconvertible currencies but allowed only "foreign currencies which have not undergone any violent fluctuation of exchange" to be counted as part of the "cash" Reserve (Kisch and Elkin 1928, p. 163-4). This was both a weakening and a continuation of the logic pioneered by Belgium some 70 years earlier when inconvertible currencies were shunned as legitimate components of the reserve but admitted as collateral.

The emphasis of Austrian lawmakers on "currencies which have not undergone any violent fluctuation of exchange" suggested foreign exchange accumulation was not conceived as a form of asset diversification but as an indirect way of holding gold. The problem was that by the 1920s the architects of central bank statutes could look to many examples of how convertibility promises could be and had been broken. ${ }^{24}$ Hence only countries with the

\footnotetext{
${ }^{23}$ Nurkse (1944), p. 28.

${ }^{24}$ A case in point was that of Serbian bonds. Serbian bonds had been issued in francs before World War I with the understanding, bondholders insisted, that this meant gold francs, although bond covenants were not explicit
} 
strongest commitment to the maintenance of convertibility had the capacity to emerge as reserve centers. The result was a hierarchical international monetary order. The situation, as envisaged in the Genoa Report, would be one in which certain of the participating countries" would come to "establish a free market in gold and thus become gold centers." These special participating countries would peg their currencies to gold, whereas the rest of the world in turn would peg to those currencies. The Bretton Woods System after World War II, in which the dollar was pegged to gold while other currencies were pegged to the dollar, was a lineal descendent of the Genoa order.

The contrasting composition of central banks reserves in reserve and non-reserve currency countries illustrates the implications of this arrangement. In late 1929, at the height of the gold exchange standard, the average proportion of foreign exchange in the reserves of 24 countries that did not produce a key currency stood at 37 per cent. ${ }^{25}$ In contrast, the Bank of England held foreign exchange equal to only 11 per cent of its combined gold and foreign exchange holdings (and foreign exchange holdings were not allowed to be included in the statutory reserve). The typed forms on which the Bank of England recorded its foreign exchange holdings listed only two foreign exchange entries (the fact that they were typed suggests that the recorders did not expect this to change this frequently): "French franc securities" and "Dollar investments." Dollar investments, moreover, made up fully 99 per cent of Bank of England's foreign exchange as of late $1929 .^{26}$ The Federal Reserve, for its part, held no more than negligible quantities of foreign exchange. This, then, was a profoundly asymmetric system, again anticipating Bretton Woods. In the republic of currencies, some currencies were more equal than others.

\section{(b) The Leverage Cycle}

A powerful procyclical element was built into this system: During expansions, nonkey currencies central banks were happily accumulating sterling and dollars, allowing them in turn to expand their own money supplies, while the key currency countries themselves did nothing to contract theirs. During contractions, when doubts might arise about the stability of key currencies, there was a tendency to flee to gold. Non-key-currency countries would dump their foreign exchange holdings and demand gold from reserve-currency central banks in return, putting pressure on the reserves of the latter, in turn forcing them to raise interest rates in an effort to rebuild their reserves (or at least to prevent them from declining further). The central banks of the key-currency countries were thus in no position to play a countercyclical role, like that of the Fed starting in 2008. The result was not unlike the leverage cycle emphasized by Geanakoplos (2009), where improvements in the quality of collateral leads to increases in leverage and credit, although central banks rather than commercial banks were at the center of the story.

The dilemmas of the gold exchange standard were evident in the behavior of the largest of all non-key currency central banks, the Bank of France. The French central bank had not entirely given up hope of regaining its pre-World War I status. The presence of its currency in the ledgers of the Bank of England and the books of Paul Einzig suggests that

\footnotetext{
about this matter. After the war, the Serbian authorities had taken advantage of the depreciation of the French franc to reimburse the bonds in paper francs, leading bondholders to litigate (Wälde 2005).

25 Nurkse (1944) p. 235.

${ }^{26}$ Sayers (1976), p. 349 ff. Archive of the Bank of England. The very limited role of the French franc as a reserve currency in this period is further documented, for other countries, by Eichengreen and Flandreau (2009).
} 
some took this possibility seriously. ${ }^{27}$ Such ambitions required following the example of the U.S. and Britain. The stabilization law of 1928 therefore defined reserves as comprising solely gold, although the Bank of France also held very large amounts of foreign exchange beyond the statutory gold reserve (Bouvier 1989, Mouré 2002). ${ }^{28}$

Holding reserves exclusively in gold was the hallmark of a key-currency country. At the same time, accumulating sterling and dollars was tempting, for it promised financial returns. Torn between these conflicting objectives, the Bank of France alternated between accumulating foreign exchange and seeking to liquidate its previously-acquired holdings. Eventually, after having at one point held nearly half of world's foreign exchange reserves, the Bank of France ended up incurring large losses when Britain abandoned the gold standard in 1931 before French central bank could dispose of its sterling holdings (Accominotti 2009).

\section{c) Market Liquidity as a Two-Edged Sword}

The Bank of France's losses were notable but not unique, Belgium and the Netherlands being other cases in point. They underscored the perils of foreign exchange markets. Gone now were the dull days of the $19^{\text {th }}$ century when the bulk of Western foreign exchange transactions took place within the narrow margins of the gold points. Even then there had been some excitement in markets for so-called "peripheral" currencies, such as the Austro-Hungarian florin in the 1870s or Argentine pesos in the early 1890s. But these problems were essentially limited to the local market (Vienna and Buenos Aires respectively). In addition, the forward market had been developed to provide hedging instruments that investors could use to protect themselves (Flandreau and Komlos 2006). ${ }^{29}$

But now the markets developed further. Atkin (2005) argues that the expansion of trading on the foreign exchange market in financial centers like London was the proximate source of the rise of exchange rate volatility. Large numbers of traders would periodically line up on one or the other side of the market. Variations over short intervals could be substantial. These variations increased the value of immediate settlement services, providing the basis for the growth of the telegraphic transfers that dominated exchange rate quotations. This transformation also enabled commercial banks, with their networks of foreign branches, to participate in this market previously dominated by investment banks which had the means to draw instruments with the highest liquidity. This evolution also increased the demand for hedging (already substantial, in the past, for Austria and Russia) and generalized the availability of forward exchange instruments (Einzig 1937) and foreign exchange options (Mixon 2009). A consequence was that shorting a currency become easier.

This was something that central banks ignored at their peril. Foreign exchange market intervention was frequent in the 1920s (Chlepner 1927, Van der Vee and Tavernier 1975, Blancheton and Maveyraud 2009). Interventions were undertaken to prepare the market for major loans, to counter speculation, and to push the exchange rate toward some target. They took a variety of forms, including standing orders in the spot market and intervention in the forward market. There were also "currency repos," a combination of spot sales and forward repurchases, or vice versa, between the central bank and its counterparties in the foreign

\footnotetext{
${ }^{27}$ See Einzig (1931) and, further, Myers (1936).

${ }^{28}$ For a view emphasizing Gallic incompetence and malice, see Johnson (1997) and Irwin (2012).

${ }^{29}$ The experience of Russia in the early 1890s also provides evidence that foreign exchange markets were by no means irrelevant: the development in Berlin of a forward market had led Russian authorities to launch their famous "ruble bear squeeze” to discourage speculation against the Russian currency (Raffalovich 1891).
} 
exchange market, as in the case of Austria's “Kostdevisen” (Einzig 1935, Eichengreen and Flandreau 2009, p. 409). Bank of France Governor Emile Moreau's memoirs describe how in 1926 foreign exchange trader Léon Verdier was loaned to the Bank of France by a leading commercial bank so that he could put together a foreign exchange department to handle these operations (Moreau 1954, p. 103). ${ }^{30}$

\section{(d) Fiscal Implications}

A complication was the interaction of treasuries and central banks over the foreign exchange policy. During World War I, treasuries increased their control of foreign exchange markets. Although the long run goal was in principle a "retreat" of political supervision, governments in practice remained reluctant to surrender all authority to the central bank, which was in the overwhelming majority of cases still a private institution. Exchange controls had become part of the standard weaponry of economic policy. At a very minimum, treasuries continued to monitor developments in this area.

Until de facto stabilization of the franc in 1926, which led to the creation of a foreign exchange department, as noted above, the Bank of France needed the agreement of the treasury in order to intervene in the foreign exchange market and was in practice regularly prevented from doing so. Interventions took a hybrid form involving the Bank of France, the Treasury (which was a large owner of foreign exchange through foreign loans), and banking intermediaries which undertook the actual interventions. It was only in 1926 that a framework was established enabling the Bank to purchase foreign exchange, and even then the Treasury retained the power of authorization.

One reason the Treasury was reluctant to surrender authority was that it shared the profits accruing from investment in foreign securities (Mouré 2002). The same mechanism came into play in reverse when the Bank of France suffered losses from the sterling crisis in 1931 and had to be recapitalized by the taxpayer (Accominotti 2008). The conflicts of responsibility and authority on foreign exchange also help to explain the subsequent creation of "Exchange Equalization Accounts” in Great Britain, United States, Switzerland, Netherlands, Belgium, France and other countries, whereby the bulk of the responsibility of dealing with exchange rate uncertainty was transferred to fiscal authorities. Contemporaries discussed the transfer of leadership from the "banks of issue" to "treasuries". Governments used technical pretexts to motivate the changeover (they invoked valuation rules for foreign exchange and gold reserves constrained their use, governments could easily endow their fund with money raising capabilities by letting them issue treasury bills). Contemporary economists emphasized instead that the exchange rate being a general interest matter, had to be dealt with by the government. Others outlined that treasuries were less subjected to public scrutiny and disclosure than central banks and thus possibly superior instruments to outsmart the market. $^{31}$

The modern debate on the fiscal effects of asset purchases thus has a $19^{\text {th }}$ and $20^{\text {th }}$ century precedent in the dispute over the management of foreign exchange reserves. The lesson policy makers derived from the 1930s was that reserve and exchange rate management was too important - or too dangerous - to be delegated to central bankers. Thus, we see here

\footnotetext{
${ }^{30}$ Until that date, the Bank of France operated through Lazards in New York. See Blancheton and Maveyraud (2009).

${ }^{31}$ Polejina (1939)., Pumphrey (1942), Howson (1980). A rigorous history of the rise of exchange equalization accounts in the 1930s is needed and would add much to our understanding of the period.
} 
the roots of modern practice in countries like the United States where monetary policy is the domain of the central bank but foreign exchange policy is the responsibility of the treasury with all the resulting tensions and contradictions.

\section{e) The Sterling Area}

The 1920s saw growing rivalry between sterling and dollar. While previous authors argued that it was not until after World War II that the retreat of sterling occurred, more recent research, including our own (Eichengreen and Flandreau), has argued that already in the 1920s the dollar had challenged sterling as a reserve currency. The newly created Federal Reserve System actively worked to create a stable and liquid market in internationally accepted dollar credits (Eichengreen and Flandreau 2012). U.S. commercial banks were authorized for the first time to branch abroad under the provisions of the Federal Reserve Act and worked to develop a market in dollar denominated bonds (Chitu, Eichengreen and Mehl 2012). Investment banks like J.P. Morgan were enlisted to sell the U.S. tranche of stabilization loans under, inter alia, the Dawes Plan to retail investors in the United States. London was by no means prepared to abandon this market, although current account problems led the Treasury and Bank of England place embargos on foreign capital calls at various points during the 1920s, forcing borrowers to look elsewhere.

The sterling crisis then was a defining moment. It conferred big losses on holders of sterling (official as well as private) and cooled attitudes toward holding foreign exchange reserves. Yet the effects of the crisis on the international status of sterling were paradoxical. The resulting depreciation of sterling, after the sharp initial drop, was not disorderly. There was a notably absence of bank failures and liquidity problems in London. Following the sharp initial drop, investors began betting on sterling's appreciation. Another casualty of the sterling crisis was the credibility of the dollar's peg to gold, which was damaged by sterling's collapse (Accominotti 2009). Given the clouds over other currencies, both the dollar or the currencies of the gold bloc, it became attractive to peg to sterling, which in turn strengthened the incentive to hold sterling balances. Amidst the general retreat from foreign exchange reserves, sterling actually managed to expand its position in central bank reserves, now principally in the Dominions and Sterling Area. ${ }^{32}$

The Sterling Area provided a relatively favorable combination of stability and flexibility. Channeling the age-sanctioned views of the banking school, the British financial system remained biased towards expansion, while at the same time offering facilities to backstop the currency and deal with crises, along with a dose of monetary orthodoxy that meant monetary policy would remain reasonably expansionary and mostly geared towards recovery. This was an attractive package which, unsurprisingly was embraced where there were powerful banking constituencies with vested interests in the prosperity of the City (as in the Dominions) and in places where the lessons of the interwar period were already digested, leading to the understanding that there were other, better focal points for central bankers than simply tracking the price of gold (Jonung 1979).

\footnotetext{
${ }^{32}$ Encouraging the creation of central banks was another mechanism for repatriating New York deposits to London. Canada was a case in point. While Canadian banks customarily relied on New York for foreign exchange services, the creation of the Bank of Canada and its cajoling by the Bank of England led this institution to hold the bulk of its reserves in London. Although it was initially pointed out that the British suggestion that the Bank of Canada should hold its reserves in gold and foreign exchange, "without specifying any minimum in gold, and at a time when the devaluation of major currencies had made holding their assets hazardous" (Cain 1996 p. 350-51). For the official British view on the subject, see Curtis (1934).
} 
Figures 1-3 summarize these interwar developments, showing the evolution of Hirschman-Herfindahl indices for holdings of gold and foreign exchange for various countries (where an index of 1 means zero diversification; the lower the index, the higher the diversification). At one end of the spectrum were countries skeptical of the benefits of diversification in the early 1920s and still very much so in the 1930s. For them, the experience of the gold exchange standard was a short-lived episode of diversification. At the other end were the countries that joined the Sterling Area; they were all early reserve diversifiers even before the Sterling Area was formed.

\section{Bretton Woods and After}

The Bretton Woods System, as we have seen, was a lineal descendent of the goldexchange standard as envisaged in Genoa. Under Bretton Woods the key currency, now the dollar, was convertible into gold (albeit now exclusively for official foreign holders), other currencies were convertible into dollars, and central banks other than the Federal Reserve were encouraged to hold their reserves not just in gold but in key currency form. "Key currency form" meant dollar form, since only the dollar was freely traded in deep and liquid markets open to international investors, official as well as private.

In practice, the system was not as simple or uniform in its structure and operation as implied by the capsule description in the preceding paragraph. Much as in the earlier goldstandard era, different countries used a variety of different instruments and structures to intervene in the foreign exchange market and manage their reserves. One case in point is Belgium, which operated a dual or two-tier foreign exchange market for much of the period, buying and selling foreign exchange at the official price (par value) to finance transactions on current account but allowing agents to transact at a market determined "free rate" for permitted capital account transactions. At the same time the National Bank adjusted policy to limit the differential between the free and official rates and hence the scope for arbitrage.

Another example was Canada, which operated a floating exchange rate from 1950 to 1962. Floating is different from freely floating, however; the Canadian authorities regularly adjusted policy in response to exchange rate movements and, in extrme cases, intervened in the foreign exchange market (Bordo, Gomes and Schrembi 2010). The Bretton Woods System, evidently, was more complicated than met the naked eye.

This system was also subject to the same contradictions as its 1920s predecessor, in the form of the Triffin, or Młynarski, dilemma. The decision for reserve managers at the level of individual central banks was in what proportions to hold gold and dollars. Once U.S. foreign monetary liabilities exceeded U.S. gold reserves in the early 1960s, the incentive was to shift from dollars to gold to avoid 1931-style capital losses on the former. That in turn threatened to precipitate the very crisis and collapse of the system that reserve managers and other policy makers presciently feared.

Or so goes the textbook story. The reality was more complicated. First, in the aftermath of World War II, the vast majority of global foreign exchange reserves - as much as 85 per cent of the total - were in fact in the form of sterling (see Figure 4). The disproportion reflected less the attractions of sterling in the 1930s (see Section IV above) than the accumulation of sterling balances by Britain's Commonwealth, Empire and allies during World War II, which they acquired to help finance their joint war effort. At the war's 
conclusion, overseas sterling was more than $£ 3.5$ billion, nearly six times the British government's gold and dollar reserves. ${ }^{33}$

Starting in 1945, the vast majority of these balances were, necessarily, blocked. That is, they could be sold only to finance imports from other members of the Sterling Area, if at all (Shannon 1950; Schenk 1994). Moral suasion was applied to the governments and central banks of Sterling Area countries. Starting in October 1946, the British government signed a series of agreements with the non-Sterling Area countries that permitted only newly earned sterling (not existing balances) to be freely converted into dollars.

These arrangements then gave way to a set of four formalized arrangements designed to maintain the usefulness of sterling, and therefore its reserve currency role, while at the same time preventing its wholesale liquidation. Members of the Sterling Area were free to use sterling to settle payments among themselves, subject only to local controls on capital account transactions. Similarly, sterling held by so-called Transferable Account economies was not convertible into U.S. dollars or any other currency, although countries with Transferable Accounts were free to use sterling to transfer payments among themselves as well as with members of the Sterling Area. So-called American Account economies (the United States and other mainly Western Hemispheric members of the dollar bloc) were able to negotiate more far-reaching concessions: they were free to convert their sterling into dollars and to use it to settle payments among themselves as well as with members of the sterling area. At the other extreme, so-called Bilateral Account countries could use sterling to settle payments with another country only with the express permission of the Bank of England. ${ }^{34}$ The nature of these arrangements reflected both the perceived danger of wholesale conversion (members of the Sterling Area with a historical allegiance to Britain were thought unlikely to engage in such practices, but Bilateral Account countries were a different matter), as well as the negotiating leverage of the foreign countries in question (as with the very different treatment of American Account and Transferrable Account countries).

Interest rates on these British liabilities were artificially suppressed insofar as the demand for sterling reserves was artificially supported by these blocking measures. Although central bank reserve portfolios were still dominated by sterling as late as the Korean War period, to see this as the persistence of a sterling-dominated international monetary system would be a misapprehension. The sterling balances were a dead weight on central bank reserve portfolios, which managers would have sought to shed had they been able to do so, rather than an active element in the monetary system.

The dollar was not subject to analogous restrictions. Consequently, after 1953 the dollar, already the key source of global liquidity, overtook sterling as the leading component of central bank reserve portfolios. The immediate postwar dollar shortage - the difficulty that other countries, especially in Europe, encountered in attempting to earn dollars - was overcome with help from the 1949 devaluations (Kindleberger 1950, Eichengreen 1993). From this point, the accumulation of dollar reserves proceeded apace. Restrictions on the use of sterling balances were progressively relaxed, and central banks engaged in their orderly liquidation. Three "Group Arrangements" were negotiated in 1966, 1968 and 1977, under which central banks pledged lines of credit to limit the impact of any large scale flight from sterling. The UK, responding to pressure from other central banks, committed in 1968 to

\footnotetext{
${ }^{33}$ And nearly a third of UK GDP. Overseas liabilities fall to half the government's gold and dollar reserves if the hard currency provided by the American loan agreement is included.

${ }^{34}$ Schenk (1992), pp.8-9.
} 
guarantee the U.S. dollar value of 90 per cent of the reserves of other countries, with the goal of forestalling flight from sterling and slowing reserve diversification.

The result, as Schenk (2010) describes, was the relatively orderly decline of sterling as a reserve currency, albeit not without outbreaks of turbulence and even crises along the way. But the key point for present purposes is that central bank reserve managers were constrained in optimizing the share of sterling in their portfolios as late as the 1970s by a combination of regulatory restraints, policies and politics. They were not able to engage in active reserve management in the normal sense of the term.

In the absence of other alternatives, the key decision in the 1950s and 1960s, the latter especially, was the proportions in which to hold dollars and gold. Here too there were restraints: contemporaries were aware of the existence of the collective action problem whereby the decision by one central bank to convert dollars into gold might provoke a run on U.S. gold reserves that collapsed the Bretton Woods gold-dollar system. Moral suasion was used to encourage central banks to maintain their dollar balances. Geopolitics - the U.S. commitment to defend its Western German ally against aggression from the east - was invoked to encourage compliance by the Bundesbank and the government of the Federal Republic. A gold pooling arrangement was negotiated under which other governments (those of Belgium, France, Germany, Italy, the Netherlands, Switzerland and the UK), acknowledging their collective interest in a solution, agreed to reimburse the United States for a portion of its gold losses. ${ }^{35}$ The gold pool did not long survive France's withdrawal in 1967. But it succeeded in putting off the day of reckoning.

These measures and others working in the same direction were designed to support the operation of the system while a successor free of its contradictions was under negotiation. Those negotiations were less than completely successful, as is well known. There was the agreement to create Special Drawing Rights to supplement dollar reserves in 1968, but their issuance was too little, too late. There was discussion of a Substitution Account to retire dollar balances in the portfolios of central banks and replace them with SDR-like instruments, but no action was taken. The result was a continued increase in the share of dollars in the portfolios of central banks, not just in the latter part of the 1960s but as late as 1977, when the share of dollar reserves peaked at close to 80 per cent of the global foreign exchange reserves. The ascent of the dollar was not interrupted, to the considerable surprise of contemporaries, by the collapse of the Bretton Woods System in 1971-3. As Hori (1986) described, "after adjusting for factors which affect the currency composition of global exchange reserves but which are unrelated to changes in countries' currency preferences, there was no large-scale diversification out of dollars into other currencies during the period under review by groups of countries. In the 1970s the adjusted proportion of dollar holdings in their foreign exchange reserves remained virtually unchanged...” Indeed the dollar's subsequent ascent was strikingly steady if Eurodollars are included along with conventional dollar reserves (again, see Figure 2).

An important force supporting the dollar in the post-Bretton Woods period was the absence of alternatives. Britain was suffering ongoing economic and financial problems; the final liquidation of sterling as a reserve currency began around 1970 and was complete by 1976, the occasion of yet another sterling crisis (Burk and Cairncross 1976). After 1972 the deutchmark was a more important component of reserve portfolios than

\footnotetext{
${ }^{35}$ The gold pool is described and analyzed by Eichengreen (2007).
} 
sterling, but that was not saying much. The German authorities resisted rapid internationalization of their currency, fearing that erratic foreign demand might somehow undermine domestic inflation control (Tavlas 1990). Starting in 1970 they introduced a special reserve higher ratio on the growth of German banks' liabilities to nonresidents as a way of discouraging foreign holdings of deutschmarks. This was then followed by a cash deposit requirement of 40 per cent on most types of new credits by nonresidents to German nonbanks in 1972 (where the cash deposit, held by the Bundesbank, did not bear interest). Variants of this measure remained in place through 1974. In addition, mid1972 through early 1974 the federal government permitted nonresidents to purchase fixed-interest deutschmark securities only with prior authorization.

Similarly, the Japanese authorities resisted more rapid currency internationalization out of fear that the financial liberalization it entailed might constrain the conduct of industrial policy. ${ }^{36}$ The capital account of the balance of payments remained strictly controlled in the 1960s; upon joining the OECD in 1964, Japan maintained exceptions ("reservations") to 18 items in the organization's Code of Liberalization. Throughout the 1970s, the finance ministry retained the authority to order the modification or cancellation of overseas lending and cross-border issuance of securities, both domestically and abroad, when it judged that the transaction would have an "adverse impact" on the economy. ${ }^{37}$ When the Japanese finally turned to financial liberalization in the 1980s, the result was an asset bubble, a bust and a banking crisis, which hardly enhanced the yen's attractions as a reserve unit. ${ }^{38}$

Markets in other currencies, meanwhile, were too small and/or illiquid to much change this global picture. Thus, to the extent that there was active reserve management in this period, it was reserve management at the margin. There were only limited opportunities for reserve managers to move out of dollars in favor of other currencies. The story of continuing dollar dominance is less first mover advantage, incumbency or persistence (as the point is variously put) than the failure, or unwillingness, of policy makers in other countries to offer alternatives.

The creation in 1999 of the euro, a currency with the scale, stability and liquidity necessary to potentially function as a first-class reserve unit, had the capacity to transform this state of affairs. It is apparent from Figure 4 that the first decade of the $21^{\text {st }}$ century saw a significant rise in the share of euro reserves, plausibly coming at the expense of the dollar. Starting in 2010, however, the Eurozone then descended into crisis, and the euro gave back some of the gains it had achieved previously. It is not inconceivable that Europe will draw a line under its crisis and that the euro will resume its ascent as an international and reserve currency. But neither does this prospect seem eminent.

The other runner in this race is the Chinese renminbi. Chinese policy makers are serious about internationalizing their currency and enhancing its attractions as an international unit of account, means of payment and store of value, preconditions for making it a more attractive form of international reserves. They are making visible progress, but they also face challenges. Currency internationalization requires capital account liberalization, and capital account liberalization is a progress fraught with risks

\footnotetext{
${ }^{36}$ For details see Bakker and Chapple (2002).

${ }^{37}$ Details are in Aramaki (2006).

${ }^{38}$ For an overview see Taguchi (1992).
} 
and difficulties. Successful currency internationalization also requires the maintenance of economic and financial stability; currently, doubts about this center on the country's shadow banking system. Successful currency internationalization requires developing the deep and liquid financial markets; currently, Chinese financial markets remain illiquid by the standards of the United States.

Finally, attracting foreign investors, official as well as private, requires convincing them that contract enforcement is reliable and that China abides by rule of law. Those foreign investors will want to see, inter alia, an independent central bank and independent financial regulator. In other words, China still has a lot of work to do before the renminbi begins to change the picture in Figure 4.

\section{Conclusion}

The reserve management practices of central banks increasingly resemble those of private financial institutions. This resemblance manifests itself in seminars and training programs that offer official reserve managers tuition in the latest portfolio optimization techniques. The World Bank runs a Reserve Advisory Management Program to advise national officials in designing an investment policy, guidelines and strategic asset allocation "to control risks... while earning a competitive market return." ${ }^{39}$ Global banks run conferences designed to educate reserve managers in private sector techniques, while at the same time advertising their availability to book the resulting trades. The Bank of Norway, who hosts this conference runs the country's sovereign wealth fund.

All over the world, central bank reserve managers report investing in a wider range of non-traditional currencies, such as Australian and Canadian dollars, and riskier assets, including equities (Pringle and Carver 2013). But investing in equities, even equity indices, is perceived as risky, and the majority of central banks remain reluctant to go too far down this road. The installed base of Canadian and Australian dollars and other nontraditional reserve currencies is so small as to barely register in Figure 4. In sum, reserve managers aspire to diversify and trade more actively, but they are constrained by the limited availability of appropriate assets to trade and diversify into. Age-old problems of risk and responsibility and liability (which had led in the $19^{\text {th }}$ century to restrict narrowly the "investment mandate" of central banks still linger). As a result, trading and diversification occur only on the margin and the effect of the subprime crisis has been to outline the resulting "lack" of safe assets.

The emergence of meaningful rivals to the dollar, whether the euro and the renminbi or something else, and experience with investing in alternatives to fixed-income securities, whether equities or something else, may change this over time and this paper has shown the secular push towards the enlargement of the scope of central bank investment. But this history we saw has also been one of disappointments. The question is whether the transition will go smoothly or, like the Bank of France with its portfolio of foreign assets in 1931, reserve managers will learn the hard way about the risks of their strategy.

\footnotetext{
${ }^{39}$ Quoted from the RAMP website (http://treasury.worldbank.org/sip/htm/ramp_africa.html).
} 
Figure 1. Herfindahl-Hirschman Indices for External Assets (Gold+FX): Various Countries ( $\mathrm{H}-\mathrm{H}$ is computed as sum of squared shares in total external reserves)

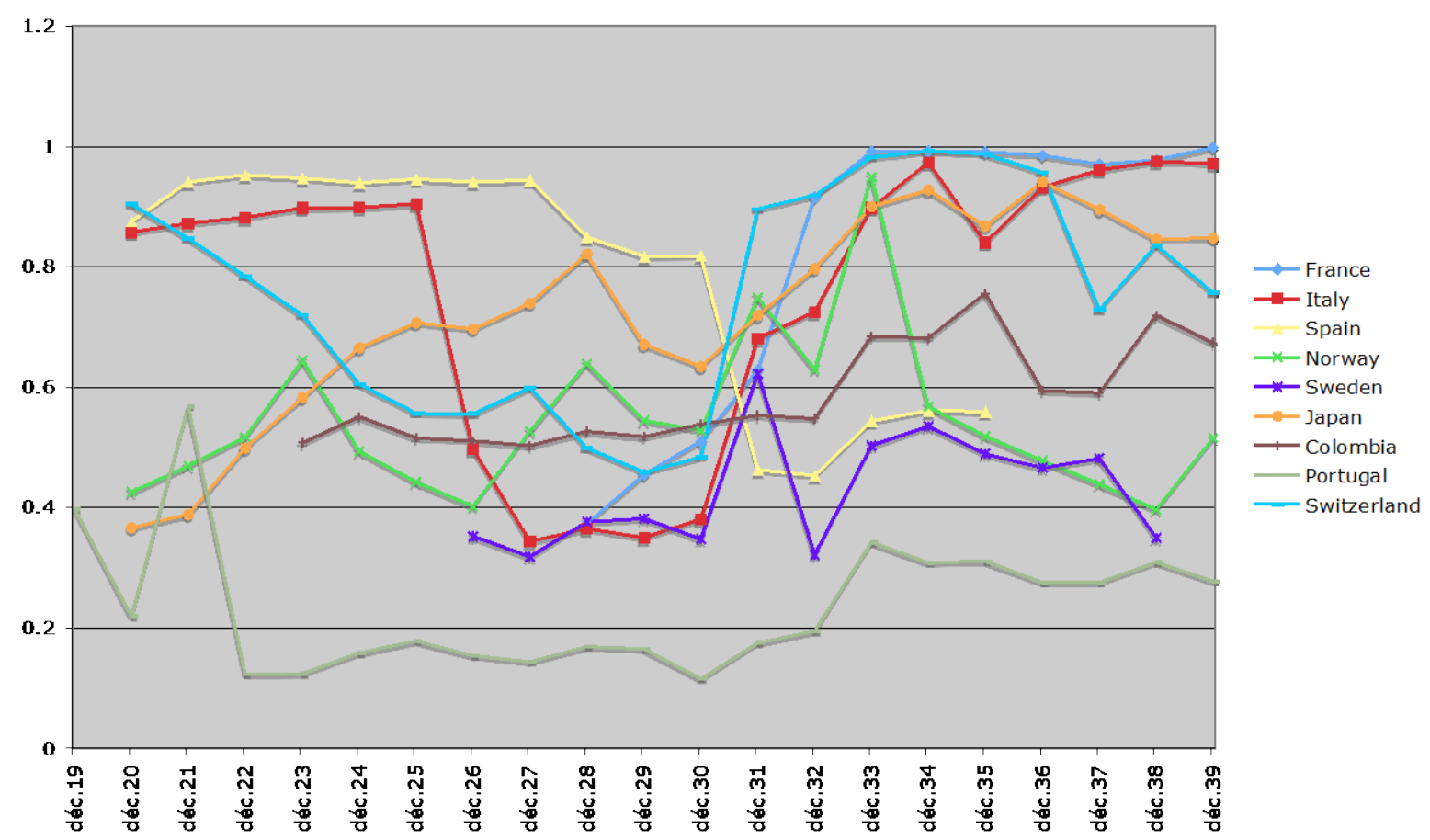

Source: Authors’ computations from Authors’ Database

Figure 2. Herfindahl-Hirschman Indices for External Assets (Gold+FX): Gold Bloc

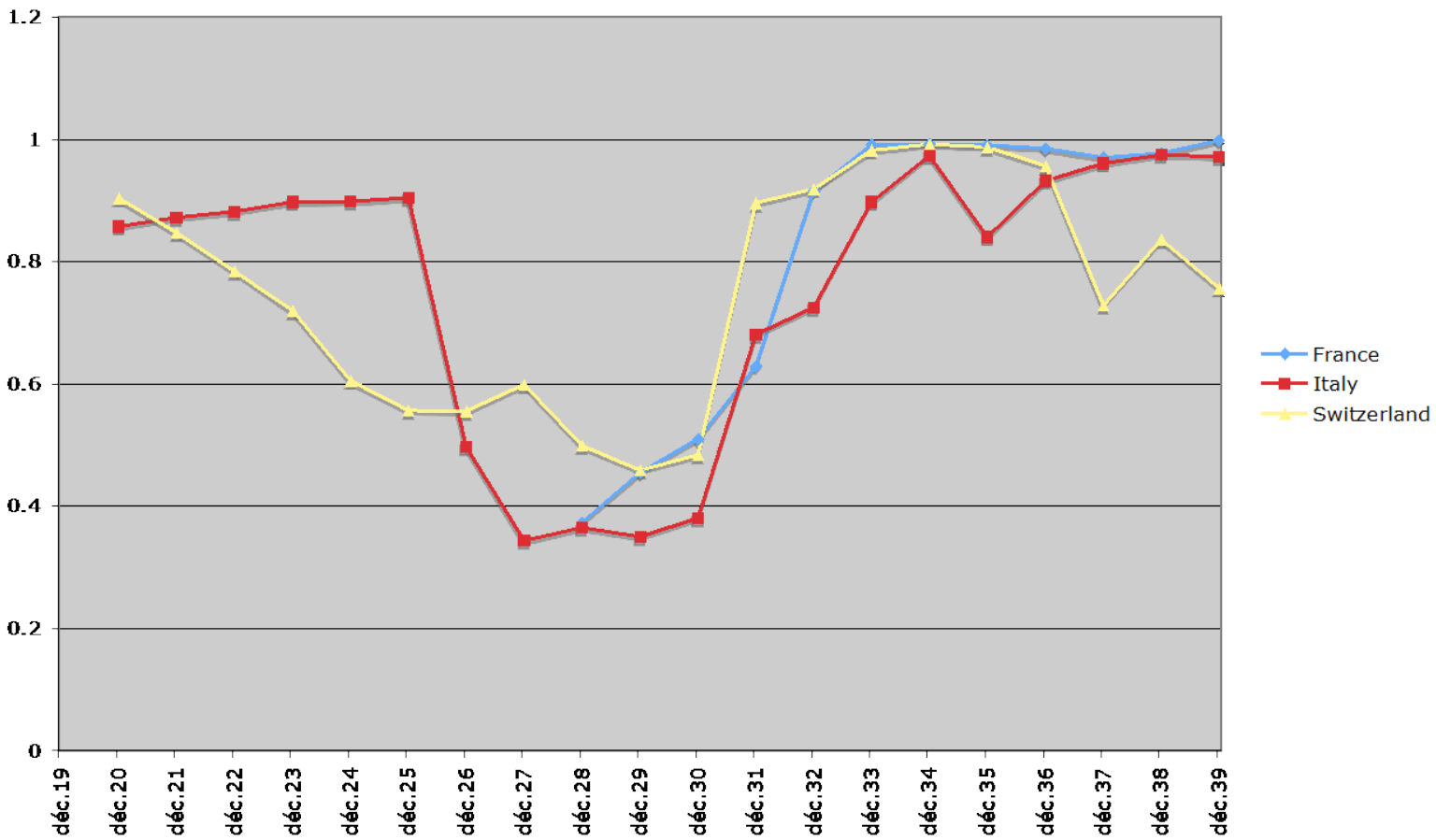

Source: Authors’ computations from Authors’ Database 
Figure 3. Herfindahl-Hirschman Indices for External Assets (Gold+FX): Sterling Countries

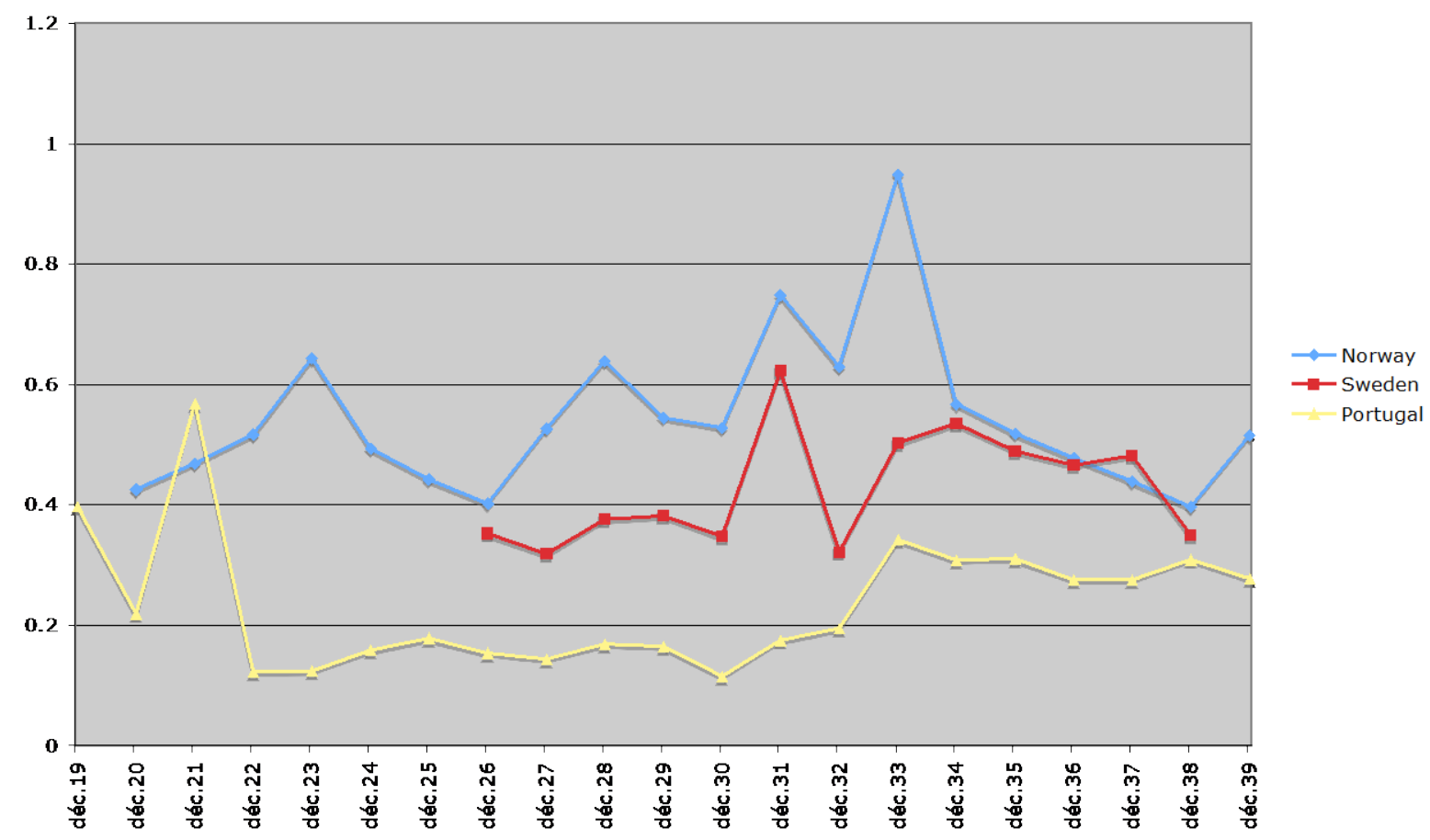

Source: Authors’ computations from Authors’ Database

Figure 4. Herfindahl-Hirschman Indices for External Assets (Gold+FX): World

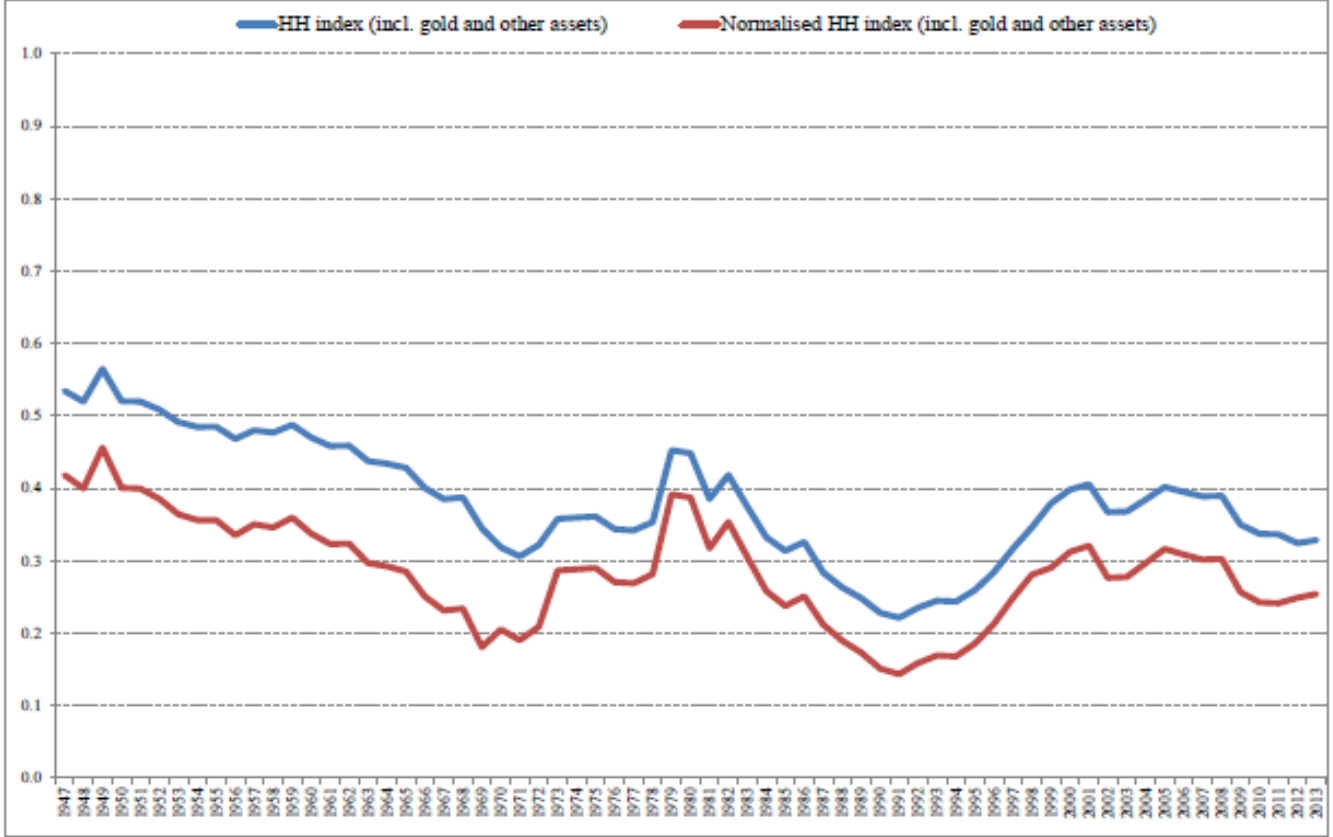

Sources: Authors' calculations based on IMF dats. Notes: the chart shows the basic and standardised Hirschman-Herfindhal indices for the brealkdown by reserve assets of total global reserve (including gold, currency and other assets) since 1947, calculated as sums of squared reserve asset shares (scaled by the number of reserve assets in each year in the case of the standardised index). Foreign exchange reserves are broken down by currency unit, as in Chart 2. An index value of 1 of 1 indicates a monopolistic market; an indes value of 0 indicates a perfectly competitive market. 


\section{References}

Aramaki, Kenji (2006), “Sequencing of Capital Account Liberalization: Japan’s Experiences and their Implications to China,” Public Policy Review 2, pp.177-231.

Accominotti, Olivier (2009), “The Sterling Trap: Foreign Reserves Management at the Bank of France, 1928-1936”, European Review of Economic History 13 (3), pp 349-376

Accominotti, Olivier (2012), "London Merchant Banks, the Central European Panic, and the Sterling Crisis of 1931,” Journal of Economic History 72(1), pp.1-43.

Aizenman, Joshua and Jaewoo Lee (2005), “International Reserves: Precautionary vs.

Mercantilist Views, Theory and Evidence,” IMF Working Paper no. 05-198 (October).

Atkin, John (2005), The Foreign Exchange Market of London; Development since 1900, London: Routledge.

Bagehot, Walter (1873), Lombard Street. A Description of the Money Market, London: King.

Baillie, Richard and Young-Wook Han (2002), "Central Bank Intervention and Properties of the 1920s Currency Markets,” unpublished manuscript, Michigan State University and City University of Hong Kong (April).

Bakker, Age and Bryan Chapple (2002), Advanced Country Experiences with Capital Account Liberalization,” Occasional Paper no. 214, Washington, D.C.: IMF (September).

Biltoft, Carolyn (2014), “Theorizing the Gaps: Ohlin, Manoilescu and Nurske” in Erik Reinert, (ed.), The Handbook of Heterodox Economics, London: Edward Elgar.

Blancheton, Bertrand \& Samuel Maveyraud (2009), "French Exchange Rate Management in the 1920s," Financial History Review, vol. 16(02), pp. 183-201.

Bloomfield, A. (1958), Monetary Policy under the International Gold Standard, New York: Federal Reserve Bank of New York.

Bordo, Michael, Tamara Gomes and Lawrence Schembri (2010), "Canada and the IMF: Trailblazer or Prodigal Son?” Open Economies Review 21 (2), pp.309-333.

Bordo, Michael and Finn Kydland (1995), “The Gold Standard as a Rule,” Explorations in Economic History 32 (4), pp.423-464.

Bordo, Michael and Ronald McDonald (2012) Credibility and the International Monetary Regime: A Historical Perspective, Cambridge: Cambridge University Press.

Bordo, Michael D., Owen Humpage, and Anna J. Schwartz (2007), "The Historical Origins of US Exchange Market Intervention Policy”, International Journal of Finance and Economics 12, pp. 109-132.

Borio, Claudio, Gabriele Galati and Alexandra Heath (2008), “FX Reserve Management: Trends and Challenges,” BIS Papers no. 40 (May). 
Bouvier, Jean (1989), “A propos de la stratégie d'encaisse (or et devises) de la Banque de France de juin 1928 à l'été 1932”. In J. Bouvier (Ed.), L'historien sur son métier. Paris: Editions des Archives Contemporaines.

Burk, Kathleen and Alex Cairncross (1992), Goodbye, Great Britain: The 1976 IMF Crisis, New Haven: Yale University Press.

Cain, P.J. (1996) "Gentlemanly Imperialism at Work: the Bank of England, Canada, and the Sterling Area, 1932-36,” Economic History Review, pp. 336-357.

Cameron, Rondo (1961), France and the Economic Development of Europe 1800-1914, Princeton: Princeton University Press.

Chandler, Lester (1958), Benjamin Strong, Central Banker, Washington, D.C.: Brookings Institution.

Chitu, Livia , Barry Eichengreen and Arnaud Mehl (2012), "When Did the Dollar Overtake Sterling as the Leading International Currency? Evidence from the Bond Markets,” NBER Working Paper no. 18097 (May).

Chlepner, B.S. (1927), 'La dépréciation et la stabilisation du Franc belge', Revue d'Economie Politique XLI, pp. 5-39.

Clavin, Patricia (2013), Securing the World Economy: The Reinvention of the League of Nations, 1920-1946, Oxford: Oxford University Press.

Conant, Charles (1910), The National Bank of Belgium, Washington, D.C.: National Monetary Commission.

Contamin (2003), “Interdépendances financières et dilemme de politique monétaire: La Banque de France entre 1880 et 1913”, Revue économique 54 (1), pp. 157-179.

Curtis, C. A., (1934), “The Canadian Macmillan Commission,” Economic Journal 44 (173), pp. 48-59.

De Cecco, Marcello (1974), Money and Empire: The International Gold Standard, London: Allen \& Unwin.

Durré, Alain and Philippe Ledent (2014), "Escaping the Macroeconomic Trilemma: The Belgian Two-Tier Foreign Exchange System under Bretton Woods,” European Review of Economic History 18 (1), pp.49-56.

Eichengreen, Barry (1992), Golden Fetters: The Gold Standard and the Great Depression, 1919-1939, New York: Oxford University Press.

Eichengreen, Barry (1993), Reconstructing Europe's Trade and Payments: The European Payments Union, Ann Arbor: University of Michigan Press. 
Eichengreen, Barry (2007), Global Imbalances and the Lessons of Bretton Woods, Cambridge, Mass.: MIT Press.

Eichengreen, Barry (2011), Exorbitant Privilege: The Rise and Fall of the Dollar and the Future of the International Monetary System, New York: Oxford University Press.

Eichengreen, Barry and Marc Flandreau (1997), “Introduction,” in Barry Eichengreen and Marc Flandreau, The Gold Standard in Theory and History, second edition, London: Routledge.

Eichengreen, Barry and Marc Flandreau (2009), “The Rise and Fall of the Dollar (or When Did the Dollar Replace Sterling as the Leading International Currency?)," European Review of Economic History, vol. 13 (3), pp.377-413.

Eichengreen, Barry and Marc Flandreau (2012), “The Federal Reserve, the Bank of England, and the Rise of the Dollar as an International Currency, 1914-1939," Open Economies Review 23(1), pp.57-87.

Eichengreen, Barry and Alan Taylor (2004), “The Monetary Consequences of a Free Trade Area of the Americas," in Antoni Esevadeordal, Dani Rodrik, Alan Taylor and Andres Velasco (eds), Integrating the Americas: FTAA and Beyond, Cambridge, Mass: David Rockefeller Center on Latin American Studies, Harvard University, pp.1289-226.

Einzig, Paul (1931), The Fight for Financial Supremacy, London: Macmillan.

Einzig, Paul (1937), The Theory of Forward Exchange, London: Macmillan.

Fetter, Frank (1965), Development of British Monetary Orthodoxy, 1797-1875, Cambridge, MA: Harvard University Press.

Fior, Michel (2008) Institution globale et marchés financiers. La Société des Nations face à la reconstruction de l'Europe, 1918-1931, Paris: Peter Lang.

Fisher, Irving, (1922), The Making of Index Numbers: A Study of Their Varieties, Tests, and Reliability, New York: Houghton Mifflin.

Flandreau, Marc (1997), “Central Bank Cooperation in Historical Perspective: A Sceptical View,” Economic History Review 50 (4), pp. 735-763

Flandreau, Marc (2003), "Crises and Punishment: Moral Hazard and the Pre-1914 International Financial Architecture", London: Routledge, p. 13-48

Flandreau, Marc (2004), The Glitter of Gold. France, Bimetallism, and the Emergence of the International Gold Standard, 1848-1873, Oxford: Oxford University Press.

Flandreau, Marc (2008), "Pillars of Globalization: A History of Monetary Policy Targets, 1797-1997”, in A. Beyer and L. Reichlin, (eds) The Role of Money and Monetary Policy in the 21st Century, Frankfurt: ECB, pp. 208-243. 
Flandreau, Marc and Gallice (2005) "Paris, London and the International Money Market: Lessons from Paribas 1885-1913” in London and Paris as International Financial Centres in the Twentieth Century, (Y. Cassis and E. Bussiere eds.), Oxford: Oxford University Press, pp. 78-106.

Flandreau, Marc and Clement Jobst (2005) "The Ties that Divide: A Network Analysis of the International Monetary System, 1890-1910", Journal of Economic History 65 (4), p. 9771007 ;

Flandreau, Marc and Clement Jobst (2009) "The Empirics of International Currencies: Network Externalities, History and Persistence”, Economic Journal 119 (537), pp.643-664.

Flandreau, Marc and John Komlos (2006), "Target Zones in Theory and History: Credibility, efficiency, and policy autonomy," Journal of Monetary Economics 53 (8), pp.1979-1995,

Flandreau, Marc and Nathan Sussman (2005), “Old Sins: Exchange Clauses and European Foreign Lending in the $19^{\text {th }}$ Century,” in Barry Eichengreen and Ricardo Hausmann (eds), Other People's Money: Debt Denomination and Financial Instability in Emerging Market Economies, Chicago: University of Chicago Press, pp.154-189.

Flandreau, Marc and Ugolini (2013) "Where it All Began: Lending of Last Resort and Bank of England Monitoring during the Overend, Gurney Panic of 1866” in The Origins, History, and Future of the Federal Reserve: A Return to Jekyll Island, in Michael D. Bordo, and William Roberds, (eds), Cambridge: Cambridge University Press.

Geanakoplos, John (2010), “The Leverage Cycle,” NBER Macroeconomics Annual 24, pp.166.

Hatase, Mariko and Mari Ohnuki, 2009, "Did the Structure of Trade and Foreign Debt Affect Reserve Currency Composition? Evidence form Interwar Japan,” European Review of Economic History 13(3), pp.319-347.

Horii, Akinari (1986), “The Evolution of Reserve Currency Diversification,” BIS Economic Paper no. 18 (December).

Howson, Susan (1980), “Sterling's Managed Float: The Operations of the Exchange Equalization Account, 1932-1939”, Princeton Studies in International Finance, № 46.

Irvin, Douglas (2012), “The French Gold Sink and the Great Depression,” Cato Papers on Public Policy 2, pp.1-56.

Jobst, Clemens (2009), "Market Leader: The Austro-Hungarian Bank and the making of foreign exchange interventions, 1896-1913,” European Review of Economic History 13, pp. 287-318.

Johnson, H. C. (1997). Gold, France and the Great Depression, 1919-1932. New Haven: Yale University Press.

Jonung, Lars (1979). "Knut Wicksell's Norm of Price Stabilization and Swedish Monetary Policy in the 1930s," Journal of Monetary Economics 5, pp. 45-496. 
Juglar, Clément (1862). Des crises commerciales et de leur retour périodique en France, en Angleterre et aux États-Unis, Paris: Guillaumin.

Kauch, P., (1950), La Banque nationale de Belgique: 1850-1918, Bruxelles: Banque Nationale de Belgique.

Kesner, R.M. (1977), "Builders of empire: The role of the crown agents in imperial development, 1880-1914,” Journal of Imperial and Commonwealth History 5 (3), pp.310330 .

Keynes, John Maynard (1930), A Treatise on Money, London: Macmillan.

Kindleberger, Charles (1950), The Dollar Shortage, Cambridge, Mass.: MIT Press.

Kisch, C. H. and W. A. Elkin (1928) Central Banks. A study of the Constitutions of Banks of Issue, with an Analysis of Representative Charters. London: Macmillan.

League of Nations (1932), Monetary and Central Bank Laws (Edited by Paul Singer), Geneva: League of Nations.

Lévy, Raphael-George, (1911), Banques d'émission et trésors publics, Paris: Hachette.

Lindert, Peter (1969), “Key Currencies and Gold, 1900-13,” Princeton Studies in International Finance No. 24, International Finance Section, Department of Economics.

Martín-Aceña, P., Martínez-Ruiz, E. and Nogues-Marco, P. (2011): "Floating against the Tide: Spanish Monetary Policy, 1870-1931”, in Anders Ögren and Lars F. Øksendal (eds.), The Gold Standard Peripheries: Monetary Policy, Adjustment and Flexibility in a Global Setting, Basingstoke: Palgrave Macmillan, pp. 145-173.

Martinez-Ruiz, Elena and Nogues-Marco, Pilar (2014): Tipo de cambio, política monetaria y controles de capital: la gestión del trilema en España, 1880-1975, Madrid: Banco de EspañaEstudios de Historia Económica (forthcoming).

Mclean, Donald (1976), "Finance and 'Informal Empire' Before the First World War," Economic History Review, new ser. Vol. 29, pp.291-305.

Mixon, Scott (2009), “The Foreign Exchange Option Market, 1917-1921” unpublished manuscript, Société Générale Corporate and Investment Banking (January).

Młynarski, Feliks (1929), Gold and Central Banks, London: Macmillan.

Moreau, Emile (1954), Souvenirs d'un gouverneur de la Banque de France: histoire de la stabilisation du franc, 1926-1928, Paris: Génin.

Mouré, Kenneth (2002), The Gold Standard Illusion: France, the Bank of France, and the International Gold Standard, 1914-1939, Oxford: Oxford University Press.

Myers, Margaret (1936), Paris as a Financial Center, London: P.S. King. 
Nurkse, Ragnar (1944), International Currency Experience, Geneva: League of Nations.

Patron, Maurice (1910), The Bank of France and its Relation to National and International Credit, Washington: Government Printing Office

Patterson, Robert H. (1870), "On Our Home Monetary Drains, and the Crisis of 1866,, Journal of the Statistical Society of London 33 (2), pp. 216-42.

Pringle, Robert and Nick Carver (2013), RBS Reserve Management Trends 2013, London: Central Banking Publications.

Pumphrey, Lowell M (1942), “The Exchange Equalization Account of Great Britain, 19321939: Exchange Operations,” American Economic Review 32 (4), pp. 803-816

Raffalovich, Arthur (1891), Le marché financier, Vol. 1, Paris: Guillaumin.

Reis, Jaime (2007) “An 'Art', not a 'Science'? Central bank management in Portugal under the Gold Standard, 1863-871”, Economic History Review, new ser. 60 (4), pp.712-41.

Sayers, Richard (1976), The Bank of England 1891-1944, Vol. 3 Appendices, Cambridge: Cambridge University Press.

Schenk, Catherine (1994), Britain and the Sterling Area: From Devaluation to Convertibility in the 1950s, London: Routledge.

Schenk, Catherine (2010), The Decline of Sterling: Managing the Retreat of an International Currency, Cambridge: Cambridge University Press.

Schiltz (2006), “An 'Ideal Bank of Issue': the Banque Nationale de Belgique as a Model for the Bank of Japan”, Financial History Review 13 (2), pp. 179-196.

Shannon, H.A. (1950), “The Sterling Balances of the Sterling Area, 1939-49,” Economic Journal 60 (239), pp.531-551.

Sunderland, David, (2004), Managing the British Empire: The Crown Agents, 1833-1914, Woodbridge: Boydell Press.

Sunderland, David, (2013), Financing the Raj The City of London and Colonial India, 18581940, London: Routledge.

Taguchi, Hiroo (1992), “On the Internationalization of the Japanese Yen,” in Takatoshi Ito and Anne Krueger (eds), Macroeconomic Linkage: Savings, Exchange Rates and Capital Flows, Chicago: University of Chicago Press, pp.335-357.

Tavlas, George (1990), "On the International Use of Currencies: The Case of the Deutsche Mark,” IMF Working Paper no. 90/3 (January).

Triffin, Robert (1947), “National Central Banking and the International Economy,” Postwar Economic Studies 7, pp.46-81. 
Ugolini, Stefano, (2011) "Foreign Exchange Reserve Management in the $19^{\text {th }}$ Century: The National Bank of Belgium in the 1850s,” Working Paper 2010/22, Norges Bank Bicentenary Project.

Ugolini, Stefano, (2012) “The Origins of Foreign Exchange Policy: the National Bank of Belgium and the Quest of Monetary Independence in the 1850s”, European Review of Economic History 16, pp. 51-73.

Van der Wee, H. and K. Tavernier, (1975) La Banque Nationale de Belgique et l'histoire monétaire entre les deux guerres mondiales, Brussels.

Von Mises, Ludwig, (1909), "The Foreign Exchange Policy of the Austro-Hungarian Bank", The Economic Journal 19, pp. 201-211

Wälde, Thomas, “The Serbian Loans Case: A Precedent for Investment Treaty Protection for Foreign Debt”, pp. 383-424 in V. V. Veeder (ed.), International Investment Law and Arbitration, London: Cameron May.

White, Harry Dexter (1933), The French International Accounts 1880-1913, Cambridge, Mass.: Harvard University Press. 